$$
\begin{aligned}
& 2+3=6 \\
& 5-1=3
\end{aligned}
$$

1. Anticonvulsant blood level $\uparrow$

2. Fits ++

3. Intelligence $\downarrow$
Learning difficulties may be due to the effects of anticonvulsants, inattention caused by unrecognised fits or underlying brain damage. Epilepsy is a family problem which can modify the lives of all members and the parents will be worried about the child's prospects for future employment, driving a car, and marriage. They may believe, wrongly, that epilepsy is always associated with mental retardation. The doctor should tell the parents that the fits are not due to a tumour, that the child will not die in an attack, and that a short fit does not injure the brain.

Dr H B Valman, MD, FRCP, is consultant paediatrician, Northwick Park Hospital and Clinical Research Centre, Harrow.

\title{
Normal haematological values and diagnosis of haemoglobinopathies
}

\begin{tabular}{|c|c|c|}
\hline Normal ranges & $\begin{array}{c}\text { Haemoglobin } \\
(\mathrm{g} / \mathrm{d} \mid)\end{array}$ & $\begin{array}{c}\text { Mean corpuscular } \\
\text { volume }(\mathrm{f}) \text { ) }\end{array}$ \\
\hline$<1$ years & $10 \cdot 5-13$ & $70-84$ \\
\hline $1-4$ years & $11.5-135$ & $74-86$ \\
\hline $4-7$ years & $11.5-135$ & $76-86$ \\
\hline Adult & $13-15$ & $80-100$ \\
\hline \multicolumn{2}{|c|}{$\begin{array}{l}\text { Mean corpuscular taemoglobin concentration is constant } \\
\text { throughout lite }(30-34 \mathrm{~g} / \mathrm{d} 1)\end{array}$} \\
\hline
\end{tabular}

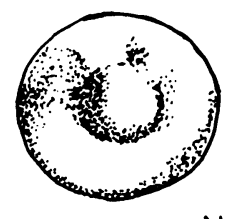

Normal
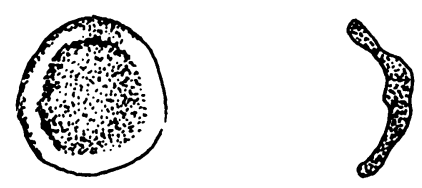

Thalassaemia

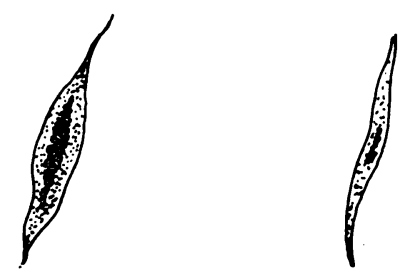

Sickle cell
Normal ranges for haemoglobin concentrations and red cell indices vary with age. The normal ranges printed on standard report forms are derived from adult studies and their use for children may result in a wrong diagnosis, especially of iron deficiency anaemia.

The child with severe anaemia due to sickle cell anaemia thalassaemia major receives an abnormal gene from each parent, who has no symptoms. In sickle cell anaemia there is a chronic haemolytic anaemia with superimposed crises due to local sickling, marrow aplasia, or acute haemolysis. Hypoxaemia causes deformity of the red cells with local sickling, which results in blocking of capillaries and further hypoxia and sickling. Ischaemia distal to the local sickling lesion causes bone, chest, or abdominal pain or infarcts in the brain, spleen, or kidneys. The child's parents who both have the trait (or a child with the trait) develop a sickling crisis or mild anaemia only if very severe prolonged hypoxaemia occurs. Diagnosis depends on detecting haemoglobin $S$ alone on the haemoglobin electrophoresis of the child with sickle cell anaemia and haemoglobin $S$ and haemoglobin $A$ in both parents.

The most common type of thalassaemia in this country is $\beta$-thalassaemia, in which there is reduced synthesis of the $\beta$-chain of globin leading to reduced synthesis of haemoglobin $\mathrm{A}$ and hypochromic microcytic anaemia. Synthesis of haemoglobin $\mathrm{F}$ and haemoglobin $\mathrm{A}_{2}$ are not affected and so the percentages of haemoglobin $\mathrm{F}$ and $\mathrm{A}_{2}$ are increased.

Two genes for thalassaemia are present in a child with thalassaemia major and one in those with thalassaemia minor. The child with thalassaemia major has severe chronic haemolytic anaemia with a very large liver and spleen and later enlargement of the frontal and malar bones due to bone marrow hyperplasia. He usually needs regular blood transfusions throughout his life. Thalassaemia minor causes mild or no anaemia. The blood picture is similar to that of iron deficiency anaemia but the mean cell volume (MCV) is disproportionately reduced compared with the red cell count (RBC) and haemoglobin levels; the ratio $M C V / R B C$ is less than 12 and the serum iron level is normal. The diagnosis is confirmed by finding a raised percentage of haemoglobin $\mathrm{A}_{2}$ or haemoglobin $F$, or both.

If thalassaemia minor is suspected during a routine antenatal clinic blood count, the father should also be tested immediately. If he also has thalassaemia minor, the possibility that the fetus has thalassaemia major should be considered and further expert opinion sought as a matter of urgency. 